\title{
Breaking his Spell: Rewriting the Mythic Female Body in Intan Paramaditha's Apple and Knife
}

\section{Gema Charmaine Gonzales}

Université Sorbonne Nouvelle - Paris III, France

\begin{abstract}
Numerous are the patrilineal mythic narratives that institutionalize unidimensional representations of women, portraying female bodies either as repositories of submission and passivity or as cesspools of chaos and corruption. Through insidious reproduction, such myths cast a discursive spell that dispossesses women of their subjectivity and agency. To break this curse and regain their voice, feminist authors have undertaken the task of rewriting old myths in ways that speak to current local problématiques. Intan Paramaditha's collection of stories, Apple and Knife (2018), is exemplary of this mission: in her speculative quill, fairy tales become reports of female body policing, vampires are symbolic of non-normative roles and a menstruation-eating monster is a counter-metaphor to misogynist scatological taboos. With a framework informed by feminist and postmodernist studies, this article explores the stylistic modes of corporeal writing in revisionist mythmaking. How are female bodies recast in revised myths in the interest of subverting standards of femininity? How does speculative fiction serve as an effective instrument in celebrating bodies symptomatically silenced in "original" texts? By fostering a dialogue between corporeal writing and revisionist speculative fiction, this paper examines how the female body may be reimagined outside what is deemed singular, natural, or authentic, both in terms of genre and gender.
\end{abstract}

Keywords: écriture $d u$ corps, feminist mythmaking, postmodernist myths, revisionist mythmaking, speculative fiction, Indonesian literature

\section{Introduction}

To veer away from the pitfall of relegating the question of myth as belonging to a distant anteriority or worse as situated solely on the fabled or non-material plane, it seems necessary to begin by pointing out how discursive conceptualizations of a normative female imaginary provoke bouts of gender-based violence that are very much real and present. In this respect, we might cite examples of narratives on the monstrous feminine that instigate concerted attacks on women in contemporary society. The occasional distancing of the European witch purge, being falsely designated as a case of the Middle Ages and not of the Renaissance, finds no solace in parts of the world where witch-hunts and wide monster eradication still take place, as in Southeast Asia. The unremitting witch killings in Indonesia, the murders of women accused of being aswang (vampires) in the Philippines, the persecution of women Dalits on the pretext of 


\section{SARE, Vol. 57, Issue 1/2020}

sorcery in $\mathrm{Nepal}^{1}$, all indicate the crossover of myth-as-truth from fiction to reality and the resulting symptomatic targeting of women whose monstrous bodies of destruction must perforce be eradicated. The premise that India's rape culture may be traced back to the vagina dentata myth $^{2}$ dilates upon this most effectively, in that it shows that to have the body of a woman, here clearly an emasculating-castrating body, is enough to make her a recipient of sexist sadism.

In an attempt to challenge unidimensional representations of femininity that prompt violence against women, feminist authors of the twenty-first century have undertaken the task of recasting ancient myths as alternative herstories that expose plural female subjectivities. One exemplar of such revision is Intan Paramaditha's anthology Apple and Knife, published in 2018 and translated from the original Indonesian to English by Stephen J Epstein. ${ }^{3}$ A lecturer of Film Studies at Macquarie University, Sydney, Australia, Paramaditha has engaged in questions of gender, female resistance, and literature as activism in the local cinematic context. But her interest in feminist concerns extends well into the worlds of her fiction whose elements often explicitly address women's contemporary ordeals. The collection Apple and Knife gathers her earlier speculative stories from Sihir Perempuan (2005) and Kumpulan Budak Setan (2010) to yield a subversive whole, distant in its emphasis on fantastic and Gothic elements yet apposite in its focus on modern women's experiences.

A great majority of the stories in the anthology reimagine local myths with a clear feminist and political agenda, reminiscent of kindred works The Bloody Chamber by Angela Carter or Feminist Fables by Suniti Namjoshi. But what especially sets apart Paramaditha's narratives is the focus on "bodies and sexuality" or in the author's own words, "bodies that are demonized-blood, slime," those themes that "we repress [...] we refuse to acknowledge" (Paramaditha qtd. in Snaije) ${ }^{4}$. One thus finds in this trove of tales new perspectives through which one may view female bodies and, with them, a language that does not shy from tabooed exclamations.

Where my selection of texts to close-read in this analysis foregrounds the juncture of postmodernist aesthetics and corporeal writing (écriture du corps), it nevertheless seeks to go beyond what is in the text and unravel its social import. What is of interest here is how Paramaditha manipulates the speculative fiction genre, postmodernist textuality, and corporeal revisionist myths in producing narratives sensible of women's contemporary plight. These narratives, as I will argue, dislodge the unidimensional imaginaries of female bodies in $u r$ - 


\section{SARE, Vol. 57, Issue 1/2020}

myths, highlight female experiences in local society, and reclaim subversive spaces where female bodies may regain agency.

As feminist thinkers have elucidated by now, early systems of thought have much to do with negative views on female corporeality (Lennon). From the Platonian somatophobic tendency to the Cartesian dualism anima/corpus of the Enlightenment, the body has been conceived as marginal, and inferior to the mind. ${ }^{5}$ In charting the genealogy of body theory, Janet Price and Margrit Shildrick claim that the devaluation of the body coupled with the partiality to the mind speaks to a "transhistorical desire to access the pure Intelligible", i.e. the highest form of rationality (2). The body is thus imagined simply as a hurdle to the satiation of this desire. Dionysian in its being governed by emotion and instability, it was considered an "object of fear and repulsion" where only senseless drives reign, and as such, a surface to be controlled and disciplined (Price and Shildrick 2-3). The mind, inversely, was deemed the site of intelligence and the Apollonian representative of the rational. The problem evinced by this dualistic model lies in the identification of the female to the body. The mind/body formulation when assimilated to the male/female dichotomy puts female bodies in the double negative. Which is to say: owing to the naturalization of the body, women were defined as the negative Other, the inferior half, pathologically "destined" to be second.

The long genealogy of mythopoesis attests to a similar proclivity towards writing on the body in its insidious labelling of corporeal archetypes. Certain female figures, recurrent in the far-flung corners of the world, reveal the androcentric and often misogynist nature of traditional myths. Dualistic thinking is once again operative, as women are hemmed in one of two extremes: as a personification of the ultimate Good (read: docile, silent, submissive) or of the ultimate Evil, the paragon of sin and chaos (Gilbert and Gubar 17). Avatars of female virtue, from the Judeo-Christian Virgin Mary to popular myth's Cinderella character, contribute to the institutionalization of ideal femininity; while the figures of female monsters, to which Eve, Medusa, Pandora, and the siren belong, participate in their diabolization. Not only is this dichotomous perspective an ontological perversion of women's material subjectivities, it is also a justification of patriarchal authority. Mythic images that are presented as universals become the index for defining the "good" or "bad" woman, which in turn vindicates the control of their bodies and speech in reality.

How such imaginaries have cut across the fictional to incite real violence towards women, as our preceding examples of extreme cases substantiate, is far from opaque. By means of reinforcement and repetition, myths are elevated to the status of unquestionable truths, 


\section{SARE, Vol. 57, Issue 1/2020}

allowing for the validation of a social action or a worldview. This kind of image-making, achieved through repetitive discourse, is precisely what I refer to when I speak of myths. Let me note in passing that my conflation of the narrative forms mythology, fairy tale, and folklore, elsewhere defined as having distinct characteristics, serves to show how these texts uniformly reinforce specific values in the objective of cementing a strict ideological configuration. Myths are "not things akin to nouns, but active processes akin to verbs" (McCutcheon 200). Meaning, they are always in-the-making, variable in that they may not be circumscribed to a set of governing laws and may not be quickly differentiated from other topologies like folktales, legends, or fables. As feminist mythologist Estelle Lauter asserts, mythic thinking is not a "stage", i.e. simply belonging to the past, but once again, a "process" that continues to be born in the present. In this process, a story or a symbol of virulence is repeated incessantly and becomes a truth that the past and the present find hard to deny, even when confronted with evidence of falseness (Lauter 1).

But whose truth? The male bias and phallogocentric attitudes in many myths have been important loci of theorization for feminist folklorists (Haase 10-11). On the one hand, they criticize the absence of female authority or the absence of women tout court in the gest of mythmaking, as did for instance Alicia Ostriker when she spoke of the disparity between mythic figures produced by female and male traditions since the 1960s-in her own words, "over a dozen" revisionist myths by women, and as for that produced by male tradition, "one cannot begin to count" ("The Thieves" 73). Like its production circumstances, the product of patrilineal myth-making is just as inhospitable to female characters: Ruth B. Bottigheimer's tabulation of the editorial manipulations of Cinderella in the Grimms' tales reveals that from 1812 to 1857 , Cinderella and the stepsisters' dialogues (the number of times they spoke) have been significantly reduced. In both its production and product, myth-making seems to have an extensive practice of silencing women.

The designation spell in folkloric and fantastic accounts may allow us to peruse the ramifications of oppressive mythmaking in a metaphoric vein, being that it is foremost evocative of a body bound by chains that though visually indiscernible, appears to have an eminently performative effect on the hexed. It not only implies but is predicated upon a punishment by way of disenfranchisement, curtailing, or completely suppressing one's freedom. The West Kalimantan folktale Batu Menangis speaks of an indolent girl who is transformed into stone by a curse; Rara Djonggrang of the Yogyakartan legend is turned into a stone, part of a temple, through a spell cast by an angered prince - at its most extreme form, the 


\section{SARE, Vol. 57, Issue 1/2020}

act of cursing equates to the act of taking one's agency, inasmuch as it removes one's status as Subject through a literal transmutation to an Object, i.e. to an Other. It is in this dreary image of epistemic violence inhabiting one's relegation to an Object that the present article's title bears its metaphoric relevance: the normalized codes of patrilineal myths invoke a textual curse that deprives women of voice, subjectivity, and agency, and thus a curse that must be broken through revisionist mythmaking.

What essentially underpins the revisionist practice is a mechanism of appropriation and abrogation. Women writers appropriate an ancient text to then canalize it towards a new purpose or meaning, thus repudiating its "logic"-founded legitimacy. Indeed, much of feminist critical engagement with revisionist mythmaking indicates a twofold deconstruction as a point of consensus. For Ostriker and Angela Carter, themselves both revisionist mythmakers, revised myths fill an "old vessel" with "new wine" to then "make the old bottles explode" (Ostriker Stealing 213; Carter 69). Feminist theorist Jane Caputi describes the process as "patriarchal myth-smashing" that seeks to give way to "woman-identified mythmaking" (427). Or yet again, it is an "act of demolition" and a "task of reconstruction", according to feminist mythologist Susan Sellers (30). In all accounts, revisionist mythmaking entails using an old text against itself, breaking the spell from within, and then supplanting an ancient perspective with aberrant new codes that challenge the old foundations.

The four short stories analyzed in the next sections expose several deconstruction strategies in revisionist mythmaking, such as inversion, poetics of duplicity, and representations of the excess. Certainly, these texts re-envision the destructive images of mythic female characterization: the evil hag in "Scream in a Bottle" and "Blood", the good-girl heroine in "Vampire", and the sadist queen in "Beauty and the Seventh Dwarf". But they do so while drawing attention to feminist issues. Where are female voices in discourses on abortion? What of female agency in predator-prey narratives? Why associate horror with menstruation? - are just some of the questions Paramaditha's revisionist myths raise.

\section{Voicelessness and Reinstituting Speech to the Silenced}

Apple and Knife grapples with questions of voicelessness and silence first through a gesture of narrative exposition that is often hyperbolically parodic. Many of the stories expose how women are brutally dispossessed of their voice to such a degree that their speech remains either unheeded or non-authoritative. In keeping with Paramaditha's nightmarish propensities, such stories illustrate voicelessness in its extreme form, designed to instill terror and uneasiness in 


\section{SARE, Vol. 57, Issue 1/2020}

its readers while prompting their engagement with women's realities. The comforting stability that any literal appraisal of these texts may provide is robbed from its readers, who, faced with satirical indicants and ironic details, are urged to confront the real violence they metaphorically stand for.

In the tale "Scream in a Bottle", female silence is depicted not as the inability of women to speak, but as the disinclination to have her heard despite her "screams". The story follows a journalist named Gita as she sets out to interview a witch known in Cadas Pangeran for her supernatural abortion services. Death and motifs of decay impregnate Gita's first impression of the witch Sumarni and her house. Sumarni's body is likened to a ghastly corpse, "sallow" and "sombre", masking the odour of graves and "departed souls". Her abode welcomes neither "a scent of life" nor the rays of the sun. It is cut off from the city with a corroding "dark fence" (Paramaditha 67), a barricade symbolizing not only the threshold of the supernatural but also, as the progression of the story will show, the fringes of nonconformity from the perspective of Gita.

As is recurrent in Paramaditha's work, the story begins by adumbrating a denunciatory and often stereotypical evaluation of mythic characters. Upon seeing the infamous Sumarni, the horror-struck Gita decides that the witch is "a sorceress allied with the devil" (Paramaditha 68). The act of abortion is prematurely relegated to an occasion of sin and Sumarni, being its malfeasant, an ally of the abyss. Even before the interview begins, Gita professes, "Yes, Lord, she will burn in hell until the strips of her flesh sizzle. Yes, Lord, may she not find forgiveness" (Paramaditha 68). Gita's presumptive reckoning of the witch's practice emulates the anxieties towards midwifery that have assailed much of the history of early modern witch purges. Midwives construed as "anti-mères" (anti-mothers) (Chollet 35), have been frequent targets of witchcraft accusations (Houd and Oakley 26). Their pivotal role in providing reproductive health care services was viewed as a menace to the regulatory mechanisms of body control established primarily by the church and the state (Houd and Oakley 26-27). Thus, while the heresy leveled against witches foregrounded a religious justification, it also intended to sustain, in concealment, the policing of the female body. The relegation of Sumarni's abortion services to religious infraction suggests a selfsame accusation while prefiguring, as I will instance later on, a social criticism on female bodily discipline.

Gita's negative view of Sumarni resonates not only with historical accounts but with the overarching portrayal of "bad" women in literary narratives. It intimates mythic lore that cast the witch as the ultimate representation of female deviation, the villain. The standoff 


\section{SARE, Vol. 57, Issue 1/2020}

between good and evil, characteristic of classic fairy tales, is satirically mimicked through the confrontation between Gita, the "nice girl", and Sumarni, who, due to her practice, has been the subject of interviews titled along the lines of "The Dark Side of Women" (Paramaditha 67-68). When Gita likens Sumarni to Mak Lampir, a witch from Javanese mythology that has been significantly present in modern pop culture, we are reminded of this discursive "baggage", of images of the green-faced "hag" with a guttural wicked laugh whose mission is to spread evil to the world. ${ }^{6}$

What is most interesting, however, is how the narrative challenges just as it exposes this staging of the witch imaginary. While in the first half of the text, Sumarni's characterization coincides with ancient myths' association of the witch to death and destruction, the second half shows the opposite, such that Sumarni becomes a bearer of life. Midway through their conversation, Gita's bigoted opinion and fear towards the witch dissolve into an intuitive camaraderie and they become "like bats, relying on each other" and who "understand each other" (Paramaditha 71). Sumarni reveals that she bottles the screams of the women who come to her for help because, save for her house, their cries are elsewhere outlawed: “A mother's scream dies with her baby. They are no longer able to speak. No one will want to hear. They are troublemakers, pariahs. What I do child, is offer a home for the screams. If I didn't, the scream would evaporate and leave the woman mute forever" (Paramaditha 71). Unlike Gita's earlier perception of the witch as a destroyer of life, Sumarni is portrayed as a liberator. Alluding to the mythological Phoenix, Sumarni explains that her work requires a noble sacrifice and the courage to "extinguish" a life "for the sake" of another (Paramaditha 69).

This explicit inversion catalyzes a change in value system within the narrative, where "what was negative becomes positive" (Sellers 27). The witch's implication in death is revoked by her act of preserving life, and the stock witch-as-villain trope is recast into a narrative about a misjudged heroine. Through this revisionist strategy, the short story brings into focus the voicelessness of female mythic characters who do not correspond to gendered status quo, while at the same time rooting out the source of this correspondence in mythic characters' portrayal as repositories of "truth". Binaries espoused in ancient texts - to which we might include the omnipresent good/evil dualism - undergird a patriarchal framework of morality and validate the institution of a skewed perspective on what it means to be "ideally" feminine. This, in turn, corroborates the status of Myth as truth and as an immutable source of universal knowledge.

Had Paramaditha presented a revised myth from the outset, the effect on readerinterpreters would not have been similar. When actuated in real time, i.e. in the very occasion 


\section{SARE, Vol. 57, Issue 1/2020}

of reading, the inversion technique allows readers to observe the revisionist mythmaking process empirically and themselves become complicit in the deconstruction of Myth-as-truth. This politicization of mythmaking that installs just as it subverts dominant ideologies may be ultimately described as a form of postmodern parody. In postmodernist critic Linda Hutcheon's words, the postmodern parody "de-doxifies" or destabilizes "our representations of the past" (94). Myth is thus deprived of its false "common-sense naturalness" (Hutcheon 32) and its appearance as an index of truth values is undermined. Inevitably, readers are encouraged to recognize the need to search for another or other multiple "truths". By refusing authority to Myth and presenting it not as a fixed jurisdiction but as a discursive social construction, Paramaditha creates a kaleidoscopic text that resists singular meanings, "suspending not disbelief", as it would simply be the case in speculative fiction, but completely truncating any "attachment to androcentric interpretative strategies" (Boehm 10). In other words, her text calls for a feminist deconstructive model of interpretation.

One of the most explicit ways that "Scream in a Bottle" encourages a feminist rereading is through its candid slippage from diegetic criticism to extra-textual satire. The narrative ricochets towards women's contemporary issues, in this case, to the question of abortion. At the end of the story, we learn that Sumarni protects the cries of women who undergo abortion, granting them a space where their voices can be heard. Muted women, whose screams are stifled by patriarchal muthos on procreation, are only able to exercise authority over their bodies in Sumarni's abode. And these repressed voices can only exist in the witch's bottles, for outside its limits, they die. This metaphor of screams preserved in bottles signals a hyperbolic articulation of the silencing and persecution of women who undergo or enable abortion. $^{7}$

At the center of contention here is whether or not women have control over their own bodies, how and in which contexts the divestment of their agency and autonomy, expressed through body authority, is justified. A long history of theorization on the body backs up this denouncement, from Michel Foucault's discussion of "docile bodies" produced by modern biopolitics through disciplinary institutions and practices, to feminist elaborations on the subject, like Susan Bordo or Sandra Bartky's sustained analyses of the female body as a locus of social control. Tracing the critical engagement with the female body in Foucault's writing, Bordo writes:

Now, feminism imagined the human body as itself a politically inscribed entity, its physiology and morphology shaped and marked by histories and practices of 


\section{SARE, Vol. 57, Issue 1/2020}

containment and control - from foot-binding and corseting to rape and battering, to compulsory heterosexuality, forced sterilization, unwanted pregnancy and (in the case of the African-American slave woman) explicit commodification. ("Feminism" 251)

Paramaditha's tale exposes the extent to which such patriarchal statutes of "containment and control" are inscribed in female anatomies and consequently criticizes its effect in women's access to agency.

As we shall see in the subsequent analyses, the desire to elicit social criticism, notably with regards to female body discipline, represents a commonality in Paramaditha's fiction. Re-vision ceases to simply mean "to rewrite", but also "to redirect vision". Ancient myths that perpetuate female socialization are revised to contemplate women's real-life experiences. The continuum of myth as political discourse is not interrupted but further accentuated through the transition from textual strategies to social criticism. By means of rhetorical techniques and inversion-in-action, not only does Paramaditha demonstrate myth qua artificial and discursive construction, she also harnesses this discursivity to design subversive narratives from the prism of lived female subjectivities.

\section{Poetics of Duplicity and the Femme Fatale}

The strategy of inversion that I fleshed out in the preceding analysis precipitates the refusal and subversion of singular truths about female bodily experiences and femininity. In this section, I present the poetics of duplicity as a related revisionist technique that rather than solely reversing binaries, problematizes their boundaries. Paramaditha's fiction is stippled with duplicitous characters who either break free from the orthodox conceptions of how they are supposed to be or who hide an alternate, but coexistent, inner consciousness. Value labels conventionally attached to emblematic characters are thus challenged, and the "clear-cut" perimeter that separates one binary element from another is ruptured.

In "Vampire", a secretary wards off her boss's sexual overture with the help of a vampire alter ego. Two voices intertwine closely in this macabre tale, that of the secretary Saras and that of her inner vampiric consciousness. Beyond the marked schism in the text's typography - the vampire Saras' thoughts are presented in italics - there is a disjunct in the two personas' personalities. Saras is a secretary who chose the career because organizing and classifying, the science of "taxonomy", appealed to her (Paramaditha 98). Her methodic and risk-averse attitude traverses her work life. On the other hand, her vampire counterpart is 


\section{SARE, Vol. 57, Issue 1/2020}

disarrayed and salacious, with a penchant for red, danger, and the macabre. An ironic oxymoron of sorts, Saras' black and white perspective on all matters is placed in complete contrast with the disjointedness of her own self.

Sustaining duplicity through its protagonist, the story accommodates from the outset an ambiguous characterization that goes against ancient myths' homogenized construction of femininity. It purposely reflects a transgressive attitude towards the "validity of the 'I', of any 'I'" such that the fixed meanings attributed to the female body are suspended. Incidentally, the illustration of "the divided self" (Ostriker "The Thieves" 88) or the self harbouring a split subjectivity is a recurrent technique of subversion in both revisionist mythmaking and corporeal writing. When possessing plural subjectivities, the body becomes an unintelligible body. It "cannot be thought" normative self.

The portrayal of the body as porous becomes even more prominent as the story comes to its conclusion. Dualistic morality is rescripted, insofar as the monstrous feminine metamorphoses into the heroine and the supposed villain, a deserving prey. Saras' boss, Irwan, invites her out to discuss an office project but with the hidden intention of being intimate with her. He brings her to a brothel and insists on taking her home after learning she lives alone. Upon arriving at her house, he begins to make his advances. The secretary Saras though trembling in fear is prepared to thwart his unwelcome solicitation and "throw him out if necessary" (Paramaditha 2019, 101). But her vampire self swoops in and seizes control:

Yet I [Saras] felt him [Irwan] getting closer and closer. Cologne and cigarette smoke wafted from his neatly trimmed hair. I felt as if-

Sucked in?

Atop the ice-cream sits a shiny, round cherry. The fruit tempts, challenges danger. Will I fall? But I want it so much. I imbibe life.

His neck is so beautiful. And I am so thirsty for blood. (Paramaditha 101-102)

Irwan goes missing the following day, implying that Saras has succumbed to her vampiric hunger. The predator/prey systematics that the narrative presages is then subverted, as Irwan becomes the victim of his own sexual aggression. Likewise, monstrosity, i.e. what it means to be or be perceived as monstrous, becomes a site of interrogation.

As in Paramaditha's other works, there is an element of social criticism that swells to the diegetic surface. In the case of "Vampire", the hidden existence of an otherkin subjectivity allows for the critique of and resistance against sexual violence in the workplace. Horror here, 


\section{SARE, Vol. 57, Issue 1/2020}

does not reside in the acts of the monstrous feminine but in the portrayal of an endemic sexual harassment. The archetypical vampire is no longer the automatic villain but a figure that counters female victimization. Not only does Saras' shifting narrative voice depart from the "purely evil" vampire archetype, it also blurs the distinction of any label branded to her body, as she becomes neither good nor bad yet both good and bad at the same time. The doublepersona underlines Saras' unintelligible body, all while challenging the either-or nature of binaristic models. By presenting a character that is at once neither-nor and both-and, the dichotomous morality that structures conventional myths is destabilized.

The reformulated feminist philosophy of corporeality that Elizabeth Grosz advocates in her now classic text Volatile Bodies: Towards a Corporeal Feminism gives us a valuable schema to deepen the analysis. For Grosz, a feminist view of the body should necessarily be predicated upon a "non-dichotomous understanding" (21) and plural models of physical representation. Saras showcases the insufficiency of envisioning corporeality through dualisms. Hers is a female body that "hovers perilously and undecidably at the pivotal point of binary pairs" (23). In being conceptualized as in-between, she represents the dissolution of bodily norms and of singular subjectivity.

Alongside this criticism of sexual intimidation, the articulation of Saras' vampiric hunger lets us read the text as a subversive response to anxieties vis-à-vis female eating. Women, in general, are compelled to refrain from excessive consumption. Eating habits are gendered such that "delicate appetites" signal correct femininity while self-indulgence indicates “monstrosity" (Talairach-Vielmas 54). In Paramaditha's story, however, the ingestion of the sanguinary excess cannot be categorized as a monstrous diet. The emphasis on Irwan's predatory tendencies renders the classification "evil" or "monster" moot, such that whoever is the villain of the tale becomes disputable. Even on a stylistic level, Paramaditha describes excessive feeding as a celebration of vitality, a way to "imbibe life" (Paramaditha 102), in stark opposition to negative perspectives on female eating as a "furtive, shameful, illicit act". Bordo's theory of an "other-oriented emotional economy" ("The Body" 18), where women are socialized to feed others instead of the self, takes a renewed definition. What Paramaditha seeks to invert, in essence, is not just the aversion towards excessive eating, but the female body seen as an object of feeding (here Irwan's lust), the female body that is not fed but fed to others. The reimagined vampiric female body is thus a consuming body that revels in forbidden decadence in favour of a self-oriented economy. 


\section{SARE, Vol. 57, Issue 1/2020}

A final tack through which one might approach this text is by looking at Saras as a figure of femme fatale, who exacts vengeance against her boss. The femme fatale, as Paramaditha portrays it, administers the revisionist strategy of split subjectivity by highlighting the figure as symbolic of "discursive unease" (Doane 3). She is in fact the duplicitous character par excellence. She resists definition, such that "she never really is what she seems to be" but is always embodying an ineffable and usually fatal enigma, as does the character Saras.

In her seminal monograph Femme Fatales, film theorist Mary Ann Doane argues that the fear associated with the femme emanates from the "power despite herself". The body of the femme holds an uncontrollable power that is outside her own subjectivity, a kind of unconscious agency (2). This, in turn, harks back to the instability of the ego "I", a menace to the male subject (and as we have indicated earlier, a selfsame menace to the masculinist imaginary of unidimensional women). Doane thus concludes that it would be fallacious to deem the femme a "subject of feminism" as it suggests more "a symptom of male fears about feminism" (2-3). While I do concur with Doane's assertion that the femme may indeed indicate the masculinist fears of female liberation, I remain critical of demarcating it wholly as such. ${ }^{9}$ Although in the case of Saras, the gained agency is accompanied by "a loss of self-awareness" (Doane 2) — her secretary self is oblivious of its vampiric counterpart - I find it more pertinent in this analysis to speak of an agency stemming from a multiplicity of subjectivities. In Paramaditha's fiction, it is less a "power despite herself" than a power in excess of herself. This excess threatens the stability of the male $I$ and, one might add, acts as a deterrent to the conceptualization of a normalized female body. But more importantly, it gives way to new, plural subjectivities through which female bodies may express empowerment.

In the next analysis, I delve deeper into the depictions of excess in Paramaditha's fiction, with particular attention drawn to the portrayal of the grotesque body and blood imagery. I reframe Doane's argument within the Kristevian tradition to trace the threat on the masculinist $I$ not as resulting from unconscious agency, but as caused by the depiction of the abject excess.

\section{Grotesque Desires and Bodies-in-Excess}

In "The Beauty and the Seventh Dwarf", a married man, recently dismissed from his company, accepts out of desperation to work for a mysterious woman as a roleplay rapist. His only task is to enact the horror story of "The Beauty of Ancol Bridge" for three months. Dressed in a 


\section{SARE, Vol. 57, Issue 1/2020}

guard's uniform, he would hide in the woman's armoire, surprise her as soon as she removes her veil, tear off her blouse, and then violate her. The man signs the contract and immediately regrets it upon seeing his new patron's discomfiting appearance. Her face is disfigured and grisly, "a rough chunk of meat" like a "tumour come to life, covered in pustules and obscene". Her body-in-excess disturbs the narrator: "It was difficult to say where her nose ended and her cheeks began" (Paramaditha 110). Only later does he realize that he had made a deal with the "devil" (113), upon associating the woman's signature in the contract with a name familiar to him. She calls herself Siti Ariah, the ghost of Ancol Bridge.

The illustration of Siti Ariah's body as "obscene" and as jutting out of its own physical confines, constitutes it as a grotesque corporeality. Mikhail Bakhtin, whose analysis of Rabelais' work cemented the theorization on the grotesque, defines it through its association with vulgar, protruding orifices. While focus is not drawn to the question of gender in Bakhtin's reading, it is useful here in illustrating the grotesque as against-the-grain of official culture, and thus a body that imperils the status quo. The grotesque body, as with Siti Ariah's, "outgrows itself [and] transgresses its own limits" rendering it, in the ordonnance of classical aesthetics, "hideous and formless" (Paramaditha 26-29). As a physicality in-excess that embodies both disproportionality and transmutability, the grotesque body can catalyze inversion.

The shift in the male narrator's perspective of Siti Ariah's grotesque body enacts a blatant reversal. In the beginning, he is gripped by fear. Despite performing the role of the ravisher, he admits that he "didn't feel like a rapist" but "more like a submissive bull [...] being led into the slaughterhouse". It is Siti Ariah, the one supposedly raped, who takes control. She smacks him, commands him to rape her and debases him as though he were a "slave", leading him to remark: "often, I felt like I was the one being raped". The experience, from his point of view as "rapist", is horrifying. Ariah's mangled face makes him weep and lose his appetite at home. She impels him to look at her "asymmetrical eyes" and her face that resembles a "putrid fish [...] [c]old, scaly, twitching." Her odour like that "of an animal" induces nausea after intercourse (Paramaditha 111-113). Suggestively, the narrator's confrontation with the grotesque escalates from psychic to physical menace.

The quasi-theatrical rendition of rape is signalled a few more times in the story, then an ironic upending is glimpsed. After a month of "raping" Siti Ariah, the male narrator starts longing for their arrangement. He begins to like being physically violated and "degraded" (Paramaditha 114). In a total role reversal, he pleads to Ariah to "hurt" and "rape" him. The inexplicable desire for Ariah so staggers the "foundations" of his world that he imagines her 


\section{SARE, Vol. 57, Issue 1/2020}

while making love to his wife and even considers running away with her, with the same monster-like face (Paramaditha 121). As the male narrator confronts his patron's grotesque physicality, his whole, "proper" identity begins to crumble. His view of Ariah's body, oscillating between strong reprehension to fixation by way of desired mimicry, elides the contradictory images produced by the disruptive yet transgressive grotesque.

There is a looking glass/mirror symbol embedded in the narrative, instituting it as a revision of Snow White, with Siti Ariah as the Evil Queen. This symbolism also indicates the resistive change that the grotesque body incites. If feminist folklorists have signalled the use of the mirror in traditional fairy tales as the phallic reflection of an ideal femininity and female eros ${ }^{10}$ in Paramaditha's fiction, the mirror is reversed and fragmented. Instead of the Evil Queen looking into the mirror for identity validation, it is the male narrator whose identity is destabilized upon looking at the Queen's grotesque body. The phallic reflection ceases to become the gauge of the "normal"; and the "normal" becomes remote, even out-of-place. In discussing female sexuality, Irigaray asserts that Western discourse imagines the female body merely as a support to the realization of male fantasies (25). Here, it is the opposite: the female body is an epicurean agent that feeds on and possesses that of the male through her own regained sexual agency.

Throughout the story, the narrator insists on the loss of his self: "I felt myself slowly sucked in"; "I was Ariah's, so she left marks on me” (Paramaditha 119-120); “Ariah's bedroom [...] had jumbled my perception of security and threat" (116). The grotesque body infringes its corporeal borders such that it can fuse with other bodies and the world. It swallows the normalized body, erases and disturbs its own limits. It is thus a locus of transgression, not simply because it is the extreme opposite of the intelligible, whole body of normative discourse, but because it is the refusal of "identity, system, [and] order" (Kristeva 4). The grotesque body is abject, if we understand this latter from a Kristevian lens as the dissolution of the limits demarcating self and other (and by extension, as the dissolution of meaning itself). Kristeva's depiction of the irresolute response to the abject in Powers of Horror: An Essay on Abjection corresponds to the male narrator's conflicting perceptions of Ariah. The abject is "a vortex of summons and repulsion [that] places the one haunted by it literally beside himself" (Kristeva 1). By being both different yet close to the Self, the abject grotesque brings fear and disgust while compelling continued attention.

Paramaditha further harnesses the subversive permeability of the body and the abject through the celebration of oft-tabooed discourses on bodily excess. In "Blood", she manipulates 


\section{SARE, Vol. 57, Issue 1/2020}

aesthetic devices to challenge period shaming and sexual anxieties. The protagonist Mara works for an advertising agency whose latest project involves a commercial on Maxi Pads. Asked to brainstorm ideas for the advertisement, Mara's team attempts to define menstruation with words like "moist", "soaked", "smelly" and "dirty", demonstrating the shame it is commonly associated with (Paramaditha 21-22). This reminds Mara how she has been instructed by her stepmother to protect her sexuality. The stepmother, tellingly named Teacher, tells Mara that women must be coy and submissive, and more importantly, that menstruation must be "buried away, hidden beneath the sea, because it was bloody" (Paramaditha 23-24). Teacher scares Mara into rigid sanitary practices with the legend of a hag who eats menstrual blood from pads left unclean by women.

Exploring the cultural history of menstruation, Elissa Stein and Susan Kim (2009) argue that the discourse on scatological blood as cross-cultural taboo persists in our days, and explicit voicing on the subject appears merely as attempts at falsely resistive marketing and insinuated sexism (1-2). Of continued relevance is Kristeva's argument that menstrual blood "threatens the relationship between the sexes [...] the identity of each sex in the face of sexual difference" (71) — the female body and its fluids remain abject, a source of horror. In narrating her traumatic experience of menstrual leak in school, Mara alludes to the female excess as a component of the horror genre: "I was like Stephen King's Carrie at the senior prom, splattered and sticky with blood all over her face, chest, arms, legs. [...] Blood is fear. Madness. Women having periods can spread terror" (Paramaditha 26). Blood imagery, as in a great number of horror texts, functions as a reflection of the incomplete subject and, subsequently, as a source of disgust for both the subject and the spectator (Creed 68-69). In a sardonic critique of the association of menstrual blood with the horrific, the narrator asks, "Has women's bleeding ever been the subject of poetry?" (Paramaditha 26). Paramaditha, through the eyes of Mara, explores the notion of menstruation as a "figurative box [...] out of sight and unmentioned" except in terms of horror and humiliation (Kim and Stein $i x$ ).

Mara's memory of her upbringing and her colleagues' reaction to menstruation opens her eyes to bodily anxiety and stigma. In the end, she declares that she doesn't want to "treat blood as an enemy" and quits her job (Paramaditha 30). In the office's restroom, she sees the creature Teacher has warned her about. But her confrontation with this creature, and her act of partaking of menstrual blood, become that of a festive celebration:

You turn around. I should be terrified, but I want to look at you. Your face is like paper in an old book, crumpled and pale. Dark circles frame eyes that 


\section{SARE, Vol. 57, Issue 1/2020}

protrude like marbles sprinkled with ash but, oddly enough, your lips are moist red, fresh. Beautiful.

"Why do you like blood so much?" I ask.

Your voice is hoarse and soft, so far away, so ancient. You whisper, "Because it's life." (Paramaditha 31)

Paramaditha projects a new way of approaching the subject of menstruation, not as the dead or as the abject corpse but as life. The metaphor of menstruation as food displaces the association of blood with the scatological negative and inspires instead its conception as a source of nourishment. Reinscribing menstrual discourse within a new value system, this revision takes part in menstrual activism, the taboo of cannibalism negates the taboo of menstruation, and succeeds in upsetting the stigmatization of the female body in its excess.

\section{Conclusion}

In order to grasp the complexity of the mythic female body's revision in Paramaditha's Apple and Knife, I favored in this analysis a progression, from the depiction of the disenfranchised body (the silenced body) to that of the overrepresented body (the body-in-excess). This structure highlighted Paramaditha's revisionist écriture $d u$ corps as a three-step process involving first an abrogation of the body-in-lack, then an exhibition of amorphous bodies, and finally, a celebration of protean, lived bodies. By "lived" bodies, I allude to how, as is evidenced by the preceding analyses, the recurrent postmodernist stylistics in Apple and Knife articulate contemporary issues of femininity such as body disciplining, sexual harassment and abortion. Revision operates through a dual movement of revising and re-visioning. It not only implies the process undertaken by Paramaditha in re-viewing to then reinterpret ancient myths but also indicates the gest of re-visioning, in the sense redirecting to a new vision, here clearly feminist. The speculative genre is a platform where Paramaditha's reimagination of female corporeality thrives. Because the speculative genre offers (im)possibilities, female bodies may be rewritten in ways that fall outside the realm of the normative status quo. The bodies of women, imagined by Paramaditha's speculative quill, overflow and burst at the patriarchal seams, breaking the spell of ancient myths simply in their very becoming.

\section{Notes}

\footnotetext{
${ }^{1}$ A brief search of online news feeds would reveal the killings of accused witches in Indonesia, particularly in the island of Java (Sims; Khidhir). The witch hunts in Nepal have been well documented by The Women's
} 


\section{SARE, Vol. 57, Issue 1/2020}

Foundation Nepal. As for the purging of aswangs in the Philippines, the online Aswang Project by Jordan Clark provides a list of all press articles linked to aswang-targeted violence in the country from 2001 to 2015. - Sims, Calvin. "Witch Hunts in Java Called a Cover for Murders." The New York Times, The New York Times, 2 Jan. 2001, nytimes.com/2001/01/02/world/witch-hunts-in-java-called-a-cover-for-murders.html.; Khidhir, Sheith. "Black Magic in Indonesia." The ASEAN Post, 3 Nov. 2019, theaseanpost.com/article/black-magic-indonesia. ; Clark, Jordan. “45 News Reports about the Aswang since 2001.” The Aswang Project, 24 Sept. 2015, www.aswangproject.com/45-news-reports-aswang/.

2 Journalist Emma Reese of the Washington Post makes this connection in her article "How the mythical 'toothed vagina' helps explain India's rape culture". Citing various myths involving the vagina dentata, she attempts to delineate the genealogy of misogynist attitudes of violence in the country. — Reese, Emma. "How the Mythical 'Toothed Vagina' Helps Explain India's Rape Culture.” The Washington Post, WP Company, 16 June 2014, www.washingtonpost.com/posteverything/wp/2014/06/16/the-stories-men-tell-to-convincethemselves-that-rape-is-okay/.

3 The translation circumstances of Apple and Knife are nevertheless particular, in that the author, also Anglophone, collaborated with the translator to reproduce the collection. While my choice to analyze the text in its English translation is primarily due to language constraints, I recognize the relevance of Paramaditha's collaboration with Epstein in reproducing the original, intended vision. - Pasaribu, Norman Erikson, and Intan Paramaditha. "A Feminist Reframing: An Interview with Intan Paramaditha." The Lifted Brow, 24 Apr. 2018, theliftedbrow.com/liftedbrow/2018/4/18/a-feminist-reframing-an-interview-with-intan-paramaditha-by-normanerikson-pasaribu. Accessed 2 Mar. 2020.

${ }^{4}$ I would like to thank Ms. Intan Paramaditha for responding to my inquiries regarding resources on her interviews. I also extend acknowledgement to Ms. Olivia Snaije for sharing her notes from Ms. Paramaditha's conference during the London Book Fair.

${ }^{5}$ In Hindu thought, we find a similar perspective with regards to the body. In the philosophical view of this theology, it is necessary to achieve a detachment from the body (gross, bodily and susceptible to contamination) in order to achieve liberation (Turner 197-8). — Turner, Bryan S., Routledge Handbook of Body Studies, Routledge, 2012.

${ }^{6}$ In the iconic series Misteri Gunung Merapi (Mystery of Mount Merapi), the hero Sembara battles against the main villain Mak Lampir in an effort to foil her plans of spreading evil to the world. Mak Lampir is rendered memorable through her expressly green face and hoarse laugh. The serial aired from 1998 to 2005, and since its premiere, has stayed in the top 5 programmes in local TV (Antariksawan qtd. in Kusumo Habsari). - Kusumo Habsari, Sri. "Fighting Bodies: The Construction of the Female Body in an Indonesian Television Serial." Intersections: Gender and Sexuality in Asia and the Pacific, vol. 19, February 2009.

7 In Indonesia, abortion is generally illegal except in cases of rape and health risks. For women's rights activist Tunggal Pawestri, "abortion law in Indonesia makes it almost impossible to protect women” — abortions performed after rape must be done within the first six weeks of pregnancy, but most women realize that they are pregnant only after ten to twelve weeks. This ambiguity shows the discrimination "against women on a number of levels, not just taking away their right to choose, but also criminalizing them". — Llewellyn, Aisyah. "Compounding Trauma: Indonesia's Abortion Law." The Diplomat, 14 Aug. 2018, thediplomat.com/2018/08/compounding-trauma-indonesias-abortion-law.

${ }^{8}$ I borrow from Spivak's conceptualization of the body as having no limits. — Rooney, Ellen, and Gayatri Spivak. "In a Word. Interview." Differences: A Journal of Feminist Cultural Studies, vol. 1, no. 2, 1989, pp. $124-156$.

9 Doane's observation that like any representation, that of the femme may eventually "take a life of its own" perhaps points to a similar refusal of circumscribing the figure to a singular definition.

${ }^{10}$ In their study on the looking-glass of the Snow White fairy tale, Gilbert and Gubar assert that the magic mirror is a tool of masculine domination in producing docile female subjects and in propagating female rivalry (36-39). This view has been seconded by other feminist folklorists. For Ellen Cronan Rose, the magic mirror 
reflects patriarchal socialization and as such, does not correspond to real female experiences; Christina Bacchilega extends the use of the metaphor to discuss how the magic mirror goes as far as structuring the discourse of desire. — Rose and Bacchilega qtd. in Haase, Donald. "Feminist Fairy-Tale Scholarship." Fairy Tales and Feminism: New Approaches, edited by Donald Haase, Wayne State University Press, 2004, pp. 1-36.

\section{Works Cited}

Boehm, Beth A. "Feminist Metafiction and Androcentric Reading Strategies: Angela Carter's Reconstructed Reader in Nights at the Circus." Critique: Studies in Contemporary Fiction, vol. 37, no. 1, 1995, pp. 35-49.

Bordo, Susan. "Feminism, Foucault and the Politics of the Body." Feminist Theory and the

Body: A Reader, edited by Janet Price and Margrit Shildrick. London and New York: Routledge, 1999, pp. 246-257.

---. "The Body and the Reproduction of Femininity: A Feminist Appropriation of Foucault."

Gender/Body/Knowledge: Feminist Reconstruction of Being and Knowing, edited by

Alison M. Jaggar and Susan Bordo. New Jersey: Rutgers UP, 1992, pp. 13-33.

Bottigheimer, Ruth. Grimms' Bad Girls \& Bold Boys: The Moral \& Social Vision of the Tales.

Connecticut: Yale UP1987.

Caputi, Jane. “On Psychic Activism: Feminist Mythmaking.” The Woman's Companion to Mythology, edited by Carolyne Larrington. London: Pandora Press, 1997, 425-40.

Carter, Angela. "Notes from the Front Line." On Gender and Writing, edited by Michelene Wandor. London: Pandora Press, 1983, pp. 69-77.

Chollet, Mona. Sorcières: La Puissance Invaincue des Femmes. Paris: Éditions La

Découverte, 2018.

Creed, Barbara. "Kristeva, Femininity, Abjection." The Horror Reader, edited by Ken Gelder. London: Psychology Press, 2000.

Doane, Mary Ann. Femmes Fatales. London and New York: Routledge, 1991.

Gilbert, Sandra M., and Susan Gubar. “The Queen's Looking Glass: Female Creativity, Male Images of Women, and the Metaphor of Literary Paternity." Madwoman in the Attic: The Woman Writer and the Nineteenth-Century Literary Imagination. Connecticut: Yale UP, 2000, pp. 3-44.

Grosz, Elizabeth. Volatile Bodies: Toward a Corporeal Feminism. Indiana: Indiana UP, 1994. 


\section{SARE, Vol. 57, Issue 1/2020}

Haase, Donald. "Feminist Fairy-Tale Scholarship." Fairy Tales and Feminism: New

Approaches, edited by Donald Haase. Detroit: Wayne State UP, 2004, pp. 1-36.

Houd, Susanne, and Ann Oakley. "Midwives in History." Helpers in Childbirth: Midwifery

Today. Washington: Hemisphere Publishing Corporation, 1990, pp. 17-36.

Hutcheon, Linda. The Politics of Postmodernism. London and New York: Routledge, 1989.

Irigaray, Luce. This Sex Which Is Not One. Translated by Catherine Porter and Carolyn

Burke. New York: Cornell UP, 1985.

Kim, Susan, and Elissa Stein. Flow: The Cultural Story of Menstruation. London:

St. Martin’s Press, 2009.

Kristeva, Julia. Powers of Horror: An Essay on Abjection. Translated by Leon S. Roudiez, New York: Columbia UP, 1982.

Lauter, Estella. "Steps Toward a Feminist Archetypal Theory of Mythmaking." Women as Mythmakers: Poetry and Visual Art by Twentieth-Century Women. Indiana: Indiana UP, 1984, pp. 1-20.

Lennon, Kathleen. "Feminist Perspectives on the Body." Stanford Encyclopedia of Philosophy, Stanford University, 2 Aug. 2019, plato.stanford.edu/entries/feministbody/.

McCutcheon, Russell. "Myth." Guide to the Study of Religion, by Willi Braun and Russell T. McCutcheon. London: Cassell, 2000, pp. 109-208.

Ostriker, Alicia. Stealing the Language: The Emergence of Women's Poetry in America. Boston: Beacon Press, 1986.

---. "The Thieves of Language: Women Poets and Revisionist Mythmaking." Signs: Journal of Women in Culture and Society, vol. 8, no. 1, 1982, pp. 68-90.

Paramaditha, Intan. Apple and Knife. Translated by Stephen J. Epstein. London: Vintage, 2019.

Price, Janet, and Margrit Shildrick. Feminist Theory and the Body: A Reader. London and New York: Routledge, 1999.

Sellers, Susan. Myth and Fairy Tale in Contemporary Women's Fiction. London: Palgrave, 2001.

Snaije, Olivia. “'Feminist Fairy Tales': Women Authors on 'Other Kinds of Books'.” Publishing Perspectives, 25 Mar. 2019, publishingperspectives.com/2019/03/feminist-fairy-tales-authors-talk-about-writingother-kinds-of-books/. 
Talairach-Vielmas, Laurence. "Drawing 'Muchnesses' in Lewis Carroll's Alice's Adventures in Wonderland (1865)." Moulding the Female Body in Victorian Fairy Tales and Sensation Novels. London and New York: Routledge, 2016, pp. 49-66. 